\title{
Public Hearing in the EIA Process of Hydropower Development
}

Bharat Mani Sharma

Abstract: This paper discusses the methodology for public hearings, mandatory legal provisions and their importance in the process of hydropower development. A public hearing is both a process of information sharing, discussion and negotiation, and an end result of allocating compensation and other impact mitigation activities. It is based on principles of equity and social justice. Any development project that brings changes to the existing biological, physical, socio-economic and cultural environment should be carefully examined considering the status of the stakeholders.

A good public hearing process can strengthen private sector incentives to help government and the people to attain a nation's hydropower development goals and, at the same time, address local opportunities and issues. A good public hearing is important for time-effectiveness, cost-effectiveness and sustainability of hydropower projects. Promises too early in the public hearing process tend to raise high expectations which, if misunderstood or unmet later on, may lead to negative consequences.

There is an urgent need to standardize public hearings in the IEE and EIA processes of hydropower projects and help proponents to conduct public hearings effectively.

Key words: Public hearing, EIA (Environmental Impact Assessment), IEE (Initial Environmental Examination), EPA (Environmental Protection Act), EPR (Environmental Protection Rules), hydropower development, Nepal.

\section{Introduction}

Thepublic, as citizens of a nation and key stakeholders in development, have the right to know and to beinvolved in information exchange and decision-making that affects their lives, resources and properties. This is especially important in infrastructure development projects such as hydropower development.

A public hearing is a gathering of interested and affected people or whole communities at which information is exchanged and views expressed. At a public hearing, concerned people can express opinions, voice their concerns and provide suggestions. It is, therefore, the general public's access to authority.

Thepublichearingisan exchangeofinformation, ideas and concerns between the public, the government and developers, with the intent of participation-to include the public in making key decisions about a project's many development issues and activities. A public hearings is based on principles of Equity and Social Justice and is both a process of information sharing, discussion and negotiation, and an end result of allocating compensation and other impact mitigation activities.

A public hearing is often the first order of involvement for local people. Many individuals may be interested but unable to read or reply to public notices due to illiteracy, lack awareness and lack of access to newspapers. Thus, the public hearing helps, encourages and enables the involvement of local people.

In Nepal most livelihoods are based on subsistence agriculture (rural smallholders and marginal farmers, including landless and near-landless people). Almost all householders depend greatly on natural resources (water, forest, pasture lands) for their livelihoods. Any development, like a hydropower project, that brings changesontheexistingbiological, physical, socioeconomic and cultural environment should be carefully examined considering their status.

When the public is well informed and motivated, project development should be relatively trouble-free. A good public hearing process should strengthen private sector incentives to help the government and the people to attain the nation's hydropower development goals and, at the same time, address local opportunities and issues.

Experience shows that a good public hearing process is important and should be:

- time-effective-ensuring timeliness and efficiency of action,

- cost-effective-reducing threat to financial investment, and

- sustainable-enabling long-term positive effects.

If the public hearing process is respected, well followed and given high priority, the end results are more likely to be positive and the people more likely to be satisfied and well motivated. Good public hearing should be representative, able to provide and share relevant information, and produce timely results for project planners and managers. Therefore, adequate representation and participation of potentially affected households, groups and communities is advocated.

Due to various reasons, however, including lack of knowledge and skill in conducting public hearings, as well as ignorance, lack of awareness, illiteracy of the local people, and communication problems, the proponents may not recognize the importance of the 
public hearing nor follow its norms. Therefore, there is an urgent need to standardize public hearing process for the mandatory Initial Environmental Examination (IEE) and Environmental Impact Assessment (EIA) processes of hydropower projects, and help the proponents in conducting public hearings effectively.

\section{Legal Provisions}

In Nepal, as per the Environmental Protection Rules (EPR 1997; 3rd Amendment, 2009) the mandatory rules of public involvement in the EIA process require both Public Notice and Public Hearing.

A Public Hearing is mandatory in the EIA process guided by the Environmental Protection Act (EPA) 1996 and EPR 1997 (3rd Amendment, 2009). The EIA process has been given the highest priority for identifying physical, biological, social, economic and cultural issues, and in planning the mitigation of potentially adverse effects of development. The intent is to minimize adverse effects and maximize the beneficial ones. This cannot be successfully done without involvement of the public.

Under the EPR 1997 (3rd Amendment, 2009), the public has the right to examine relevant project information and make their concerns, opinions and suggestions known to the proponent and other concerned authorities. Similarly, the Water Resource Act 1992 and Electricity Act 1992 also recognize the important role of public involvement in the hydropower development.

As per the EPR 1997 (3rd Amendment, 2009), there are several steps in the EIA process where the public as key stakeholders are directly and indirectly consulted regarding any development proposal and their environmental concerns (physical, biological, social, economical and cultural) are acknowledged.

Scoping is conducted to identify key environmental issues that will guide the development of the TOR (Terms of Reference) document for an EIA study. The area and focus of effort is defined, and the methods to be employed through consultation and public participation with affected groups are planned. As specified in the EPR, during the scooping period a public notice in the daily national newspaper is required to inform the public:

In regards to any proposal requiring Environmental Impact Assessment (EIA), the proponent shall publish a notice in any national level daily newspaper, requesting the Village Development Committee (VDC) or municipality where the proposal is to be implemented, as well as the schools, hospitals, health posts and concerned individuals or institutions of that area, to offer in writing their suggestions concerning the possible impact of the implementation of the proposal on the environment within a 15 day time period. (EPR 1997, 3rd Amendment, 2009)

After publication of the notice "anyone who wishes to offer his opinion and suggestion in that connection may offer his opinion and suggestions to the concerned proponent within 15 days form the date of publication of such notice...”.

As per the same amendment, public notice is required regarding IEE report:

Whilst preparing the report, the proponent shall, in the cases of Initial Environmental Examination [IEE], affix a notice in the concerned Village Development Committee (VDC) or Municipality, office of the District Development Committee(DDC), school, hospital and health post requesting the Village Development Committee or Municipality and District Development Committee or concerned individuals or institutions to offer their written opinions and suggestions within 15 days with regard to the possible impact of the implementation of the proposal on the environment where the proposal is to be implemented, and prepare a deed of public enquiry (muchulka) of that deed. The said 15 days notice shall also be published in a national level daily newspaper. After the publication of such notice, the opinions and suggestions so received... shall also be included in the report. (EPR 1997, Ch.2, §7 (2))

According to EPR 1997 (3rd Amendment, 2009), after approval of a proposal to conduct an IEE or EIA, public notice is also required to be published. A public notice in a national daily newspaper should be accurate, clear and concise. The language should be simple and without technical jargon. The notice should indicate how further information can be obtained. The operative rule is:

...the Ministry shall issue a Public Notice in any one daily newspaper, granting a time limit of 30 days [from first date of publication], to the general public to make a copy themselves of the report received along with the proposal on their own or to study it for offering their opinions and suggestions on it. (EPR 1997, Ch.2, §11(2))

After preparation of the EIA report by the proponents, a public hearing is held where concerned stakeholders have the opportunity to engage in face-to-face contact with the implementing authority/proponents. This is an interactive session where the people may express their concerns, dissatisfactions and demands. Questions are asked and satisfactory answers are expected from the both sides. Further to the rule:

...whilst preparing the report of Environmental Impact Assessment, the proponent shall organize a Public Hearing about the proposal at the area of Village Development Committee or Municipality where the proposal is to be implemented and collect opinions and suggestions". (EPR 1997, Ch.2, §7 (2))

Based on the public opinions and suggestions received through the Public Notice and Public Hearing processes, the Ministry of Environment, Science and Technology (MOEST) forms a committee to assess the EIA study, prior to granting permission to proceed with the development proposal. 
The purpose of all the legal provisions is that the proponent should follow the environmental norms and rules, and perform accordingly for sustainable hydropower development.

\section{Methods of Conducting Public Hearings}

Public hearings should be conducted at places most convenient to the affected public, and should include involvement by disadvantaged and vulnerable groups, including women. Since the developer is required to solicit agency, community, NGO (non-governmental organization), CBO (community-based organization), and general public feedback, it is recommended that the public be 'sensitized' to the process and enabled to make their voice and opinions frankly during the process.

Public hearings should be facilitated by professionals. They should ensure wide coverage of issues and be transparent. These factors will help increase credibility and trust.

During the public hearing. the project and the public involvement process should be explained to the target groups with proper rapport building for their active and meaningful participation.

Each public hearing should also include mention of how issues raised by householders, community leaders and other concerned stakeholders will be addressed. Where involuntary resettlement is unavoidable, the public hearing should involve discussion about the types and expected values of compensation available. Due consideration must also be given to issues of socioeconomic and cultural stability and physical location of resettlement.

Promises too early in the public hearing process tend to raise high expectations which, if misunderstood or unmet later on, may lead to negative consequences. When a promise is given under proper authority, the developer should be prepared to put it in writing, in a memorandum, with a timeline and other specifics. When very general suggestions about compensation or other action are given early, they should be described as 'talking points' for discussion later.

Where misunderstandings arise, strikes (bandh) and protest typically follow. Strikes hinder hydropower project activitiesin both theshortand thelongterm. Oneproactive way of heading off conflicts over misunderstandings is to assure that all involved have a clear idea of their roles and responsibilities; i.e., the proponents, local people, government line agencies and other, where appropriate.

The following points should be considered for the public hearing:

- proper communication/information;

- accessible location and appropriate timing for the public;

- participation/representation of target groups including women, indigenous and disadvantaged groups;
- $\quad$ rapport building and warm-up;

- $\quad$ topic guide to facilitate the discussion;

- identification of major issues and possible alternatives to the proposed action;

- adequate time in which to comment; and

- $\quad$ proper recording of all concerns expressed.

Public hearings should be conducted considering accessibility, participation and representation of the stakeholders by project type and nature. Public locations such as a school, health post and VDC office could be proper places to conduct public hearings.

During a public hearing, promises are recorded, misunderstandings are clarified, and both the public and the hydropower developer strive establish a better chance of getting along well together.

While a public hearing may appear to be the simplest and most direct way of gaining contact with the people, it can also be one of the most complex, unpredictable and demanding. The number of such hearings will depend upon thecomplexity of the hydropower project. Morethan one public hearing in different locations may be required when there is a large impact area and or potentially controversial issues of the hydropower project.

Good, open and frequent communications of hydropower developers could help encourage dialogue and reduce misunderstandings with the stakeholders. The stakeholders should be provided following information during a public hearing:

- project purpose;

- project type/project size;

- project location/site;

- impact area (high and low/DDCs, VDCs, municipalities);

- impacts (physical, biological, social, cultural economic, etc.); and

- potential opportunities (without raising expectations).

\section{Stakeholders}

A stakeholder in the hydropower development is any individual, group, agency or organization affected by a project and/or with concern or interest in a development project and its outcomes, or in the common resources impacted by a development project. A stakeholder is a 'Partner in Development.'

There are many potential stakeholders/partners of hydropower development projects. Some, like the local public, are involved at all stages, throughout the life of a project; and they are often affected by it for years afterwards. Others become more or less important during various stages of the project development and implementation process.

The effects of a hydropower project on stakeholders can be adverse or beneficial, direct or indirect, sooner or later. The identity of the stakeholders, the timing of their involvement and the activities they may be encouraged 
and enabled to undertake depend largely on the type, size and location of a project and on the insightfulness, creativity, sensitivityand dedication to publicinvolvement of the developer and his team.

Local people, i.e., those most directly affected by a hydropower project, are the key stakeholders. They are at greatest risk; they feel the impacts most intensely; they benefit the most from opportunities; hence, they should be the first to be involved. The poor, landless, indigenous nationalities (janjati), and other vulnerable and marginalized people are among these stakeholders, but it is they who are often the most difficult get involved.

Since local people are key stakeholders over most of the life of a hydropower project, their involvement and participation from the beginning is crucial to project success. The clearer the terms of public engagement and the more meaningful their involvement, the smoother and more sustainable and less conflicted the outcome will be.

Besides the general public, various agencies and organizations, including DDCs, VDCs and municipalities, NGOs/CBOs, ministries, government offices, commissions, councils, secretariats and other authorities, may also play key roles as stakeholders in hydropower projects.

Bharat Mani Sharma, MA (Economics) has 30 years of experience in research, evaluation, training and project management in the areas of socio-economic development, environmental impact assessment, hydropower development, natural resource management, forestry, drinking water, irrigation, agriculture, community development, education, health, advocacy and good governance.

Corresponding address: btmadia@yahoo.com

\section{References}

DOED, 2001, Manual for Public Involvement in the Environmental Impact Assessment (EIA) Process of Hydropower Projects, Kathmandu: Department of Electricity Development.

DOED, 2004, Manual for Conducting Public Hearings in the Environmental Impact Assessment (EIA) Process for Hydropower Projects, Kathmandu: Department of Electricity Development.

GoN, 1997, Environmental Protection Rules, Kathmandu: Government of Nepal.

\section{WATER SCARCITY IN VALLEY Kathmandu to be next Mexico City?}

Despite frequent warnings by experts about the risk of land subsidence due to uncontrolled extraction of underground water, authorities have failed to check the practice. Kathmandu Upatyaka Khanepani Limited (KUKL), the utility responsible for the distribution of potable water in the Valley, alone pumps around 60 million litres of groundwater each day -60 percent of water it distributes.

Star hotels and business complexes are also largely dependent on underground water, with the extent of their exploiting the source soaring each new day. Ground Water Resource Management Board (GWMB) estimates groundwater extraction to be two million litres daily. At the rate, 23 million cubic metres of groundwater is pumped out in Kathmandu valley annually, while only 14 million $\mathrm{cm}$ is recharged in the period, said Gopal Sigdel, water expert at the irrigation ministry. "This difference in water consumed and that replenished is sure to cause land subsidence in the Valley soon. Unfortunately, policymakers seem indifferent to the risk," he said. "There is no policy on monitoring and controlling it," said Pramod Raj Sharma, GWRB director. "We are planning to draft a policy together with the KUKL and Water and Energy Commission." Sharma said underground water is depleting by two-and-a-half meters every year in the Valley. "We are aware of the threat but can do nothing without a policy in place," he clarified.

Engineer Ishwor Raj Onta said haphazard pumping out of water should be checked before it is too late. "If the present trend continues, we'll face the problem of sinking land in a matter of few years." Experts have urged the government to allocate space to dig ponds for recharging groundwater at a time when fertile land here is fast turning into a concrete jungle.

For example, Mexico City is sinking since much water has been pumped out from the aquifer beneath it to satisfy 18 million residents in the metropolitan area. Some areas, such as the central metropolitan region, have fallen as much as 8.5 meters, causing damage to many buildings and ancient monuments that are located in these sections.

\section{Mahavir Pun Involved in Hydropower Project}

Magsaysay Prize winner for starting wireless internet in Remote areas of Nepal Mr. Mahavir Pun is now involved in Hydropower sector. He is the Guardian of the Hydro Promotion Company. He has team up with Pandit Din Bandu Pokharel, Chartered Accountant Raju Shiwakoti and Engineer Shree Ram Neupane. Shiwakoti and Neupane had purchased the license from Dichyya Hydropower. This 5MW project will cost Rs. 700 Million. Water from Trishuli river at $1 \mathrm{~km}$ from Dunche will be diverted for electricity generation. Fifty One Percent share will be offered to the people of the district. Pandit Din Bandhu will organize Mahayagya in Dunche and Kathmandu and collect resources for investment in the said project.

The Ministry of Forest and Soil Conservation has already provided approval for the project.

(Source: Kantipur) 